\title{
Spanish Civil War Caves of Asturias in Archaeology and Memory
}

\author{
J. Fernández Fernández and G. Moshenska
}

\begin{abstract}
As the Spanish Civil War drew to a close, retreating Republican troops in the northern region of Asturias took refuge in caves in the mountains from the brutal victor's justice of the Francoist forces. In this paper we examine three of these caves in the context of the Civil War experiences of the rural municipality of Santo Adriano, based on a combination of archaeological recording and oral history interviews. The paper focuses on the role of the La Ponte-Ecomuseum, a grassroots heritage organisation that has worked to preserve and communicate the tangible and intangible heritage of the district. The Civil War heritage presents cultural, political and practical challenges for the museum: nonetheless it has succeeded in establishing an ongoing programme for its communication and protection.
\end{abstract}

\section{Keywords}

Conflict heritage, Ecomuseums, Memory, Negative heritage, Oral history

\section{Introduction}

In this paper we examine the work of a community-based heritage organisation in collecting, archiving and promoting the marginalised heritage of the Spanish Civil War era. We draw on a dynamic theoretical framework for the generation and articulation of conflict memory narratives based in the work of Ashplant, Dawson and Roper (2000) and developed by Moshenska (2010) to examine the role of small commemorative organisations and the strategies they employ to promote subaltern historical narratives. Through this theoretical lens we examine a community-based research project that took place in the municipality of Santo Adriano, a small rural community in the centre of Asturias. The project employed oral history and archaeological survey to examine three caves in the region that were used as refuges or operating bases by Republican militiamen at various points during and after the Spanish Civil War, and where traces of occupation remain in the form of graffiti carved into the limestone cave walls. The research was carried out under the auspices of the La Ponte-Ecomuseum in Santo Adriano, a community-based heritage organisation. The final part of the paper examines how the museum is maintaining the local community heritage of these Civil War caves, and considers its strategies for the future.

\section{La Ponte-Ecomuseum and the dynamics of memory}


La Ponte-Ecomuseum is a community-led initiative by a group of academics, heritage professionals, amateurs, volunteers, and neighbours (Alonso González and Fernández Fernández 2013). Its aims are focused on the study, preservation, enhancement and diffusion of local cultural heritage in Santo Adriano (Figures 12 ). The ecomuseum has its own infrastructure and its governance is based on councils of the members organized into working groups for research, education, conservation and other matters. The ecomuseum aims in particular to highlight and enhance cultural heritage that has been disregarded or forgotten, and to create opportunities for both sociocultural and economic development in rural areas. For these reasons the ecomuseum considers itself a knowledge-based social enterprise, managing heritage resources in order to generate economic activity, development and innovation from a 'social base' (Fernández Fernández, Alonso González and Navajas Corral 2015). Among its range of community activities, the Ecomuseum frequently organizes workshops in traditional music, bringing together members and neighbours.

The activities of ecomuseums have been largely neglected in studies of community heritage, even in work focused on participatory working practices (e.g. Atalay 2012; Atalay et al. 2014; Moshenska and Dhanjal 2012; but see Moyer 2007). Nonetheless, there is a growing number of interdisciplinary research projects based around ecomuseums (see Kimeev 2008 for an example from Siberia). The work examined in this paper draws on the core heritage-based activities of the La Ponte-Ecomuseum including archaeological fieldwork, oral history, and the general study and understanding of local history with and within the local community.

The heritage of the Civil War remains a painful, difficult and divisive topic within Spanish society: the fear-induced self-censorship of the fascist era gave way to a 'pact of silence' in the following decades, and powerful traces of both endure into the present (Preston 2006; Renshaw 2011). The excavations of mass graves since the start of the twenty-first century were in part a younger generation's response to this heavy silence, and the work of the archaeologists and forensic anthropologists continues to generate political controversy and popular discomfort on local and national scales.

To consider the potential functions of La Ponte-Ecomuseum as a nexus for Civil War heritage discourse we need to consider the dynamics of contested memories of conflict and the roles of different actors. Scholarship in memory studies has long moved beyond simplistic dichotomies of 'individual' and 'collective' memory towards a more nuanced understanding of the roles of communities and social groups in mediating commemorative processes and acting to promote specific narratives (Moshenska 2010). Winter and Sivan consider how an individual might 
engage in memorial processes 'as a participant in a social group constructed for the purposes of commemoration' (1999: 10), calling collective remembrance 'the activity of individuals coming together in public to recall the past'. The question remains of how we can conceptualise the role of the La Ponte-Ecomuseum in this process.

Ashplant, Dawson and Roper (2000: 16) describe the dynamics of conflict memory as "the struggle of different groups to give public articulation to, and hence gain recognition for, certain memories and the narratives within which they are structured". These authors' conceptualization of conflict memory offers insights into the role of the Ecomuseum in preserving and promoting the local heritage of the Spanish Civil War. The model developed by these authors is based on three key components: (1) memory narratives produced by collective remembrance, the forms in which the past is communicated; (2) arenas of memory articulation, or the spaces (physical or social) in which social actors promote specific narratives; and (3) agencies of memory articulation, the groups or movements that promote or defend their specific memory narratives. As they note, "analysing specific instances of war memory and commemoration in these terms can help to clarify its politics, by specifying which social groups, via what agencies, are the promoters of a particular narrative addressed to which arenas." (Ashplant, Dawson and Roper 2000: 17).

In applying this model to the archaeological study of recent conflicts, Moshenska (2010) noted that archaeological projects can serve as arenas for promoting subaltern memory narratives through the action of stakeholder organisations, particularly where those projects are made accessible to the public and/or include oral history work. In the case of the La Ponte-Ecomuseum this is particularly applicable as the museum serves as both the instigator of the project and as the key community stakeholder in heritage discourses.

The applicability of the memory articulation model to the La Ponte-Ecomuseum's work on the Civil War caves depends on several issues. Firstly, what role does the Ecomuseum play in the creation of memory narratives around the heritage of the Spanish Civil War? Secondly, what strategies do they employ to promote these narratives? Finally, in which physical or social spaces are the heritage narratives projected? Examining the work of the La Ponte-Ecomuseum in these terms offers insights into the value and significance of its work on the local heritage of the Spanish Civil War and its wider function as a stakeholder in community heritage.

\section{Historical Background}

The Spanish Civil War was an extraordinary episode in Spanish, European and world history, arguably foreshadowing the Second World War in the European 
theatre in its political divisions, protagonists, technologies, strategies and tactics (Alpert 2004; Beevor 2006; Preston 2006). The Civil War began in July 1936 with a military coup against the recently elected coalition government of the centre-left Frente Popular or Popular Front. In the years leading up to the coup there had been a gradual move towards a more socially, economically and religiously liberal society, based on legislation and a new constitution. These progressive moves were resisted by the Catholic church, the military and the wealthy and simultaneously criticised as half-measures by the far-left parties and trade unions, leading to a wave of strikes, uprisings and political murders in the period leading up to the outbreak of war.

It is impossible to adequately summarise the Spanish Civil War in a few paragraphs, but for the purposes of this study it is worth giving an outline framework. The Nationalist forces, led from early in the war by General Francisco Franco, received material and advisory support from Nazi Germany and fascist Italy, while the Republican forces loyal to the government later received aid from the Soviet Union and to a lesser extent from Mexico, following the refusal of aid from France, Britain and other democracies. The Nationalists were able to seize control of the military garrisons and associated munitions and supplies in many major towns including Oviedo, capital of the Asturian province (Figure 3). In the early stages of the war the Nationalists controlled the south and west of Spain and advanced rapidly across the north, including Asturias, as well as beginning the long-running siege of Madrid. The fall of Madrid in the spring of 1939 led to the final defeat of the Republicans. During the war mass-murders of civilians had occurred in areas occupied by both forces: as vigilante violence in Republican areas with around 48,000 victims and as an organised, openly-proclaimed programme of extermination and social cleansing in Nationalist-controlled areas with estimated numbers of victims ranging from 100,000 to over 200,000 (Preston 2006). In the aftermath of the Nationalist victory the killings continued, targeting a range of groups including socialists, communists and anarchists of all stripes; members of trade unions and opposition political parties; intellectuals; freemasons; atheists; Protestants and others deemed unwanted in the new Spain (Beevor 2006). The progress and aftermath of the war as it affected the municipality of Santo Adriano will be discussed in the oral history section below.

\section{The Oral History Project}

The collection of oral histories that formed the basis for this project was a personal initiative of author Jesús Fernández, conducted between 2004 and 2011, and aimed primarily at the collection of general information about local history and the lives of the interviewees in Santo Adriano, an area of approximately 22 square miles with a registered population of approximately 250 , and a year-round population of roughly half that. Of the narratives collected, ten included significant 
amounts of information about the Spanish Civil War: seven interviews conducted in Villanueva; two in Castañéu, and one in Sabadía. Three of the interviews were recorded as video, seven as audio only. At the time of writing only two of these ten interviewees are still alive. The interviews were carried out in the homes of the interviewees, in public places, and in the fields near to their homes. The archive of recordings is held by the La Ponte-Ecomuseum in Villanueva.

The interviews took the form of conversations or open interviews, and were not deliberately focused or directed towards the subject of the Civil War. There is an enduring and well-attested reluctance to discuss the Civil War amongst most older people in Spain, based in part on the enduring memorial legacy of fascism, and what has been termed the 'pact of silence' in Spanish society (Renshaw 2011). The interviews focused on local place-names and local history in general, including folk traditions and stories. Where the subject of the Civil War was mentioned in the discussion it was raised by the interviewees, and was only then pursued after establishing that they were willing to discuss it.

One of the most notable features of the oral histories was the distinction between the historical timeline of the Civil War in the region and local perceptions of the conflict. In this particular case study area, the majority of the violence occurred after the official end of the war in the area in October 1937, therefore the interviewees associate this date with the beginning, rather than the cessation of hostilities. Drawing on their recollections the history of the Civil War in the Santo Adriano district can be divided into three periods.

\section{Stage 1: July 1936 to October 1937}

During this period the military front was never closer than 25 kilometres from the municipality of Santo Adriano, the nearest fighting being the siege of Oviedo. There is no evidence of political or ideological killings in the area, and the only casualties reported are young militiamen from the area who fought on various fronts, some of whom died and their bodies were subsequently returned home for burial. This is recorded in the municipal records.

During this period the most politically active members of the community launched a socialist revolution, based on the formation of a local organising committee $L a$ Cooperativa. The function of La Cooperativa was to control the production and distribution of food, clothes, footwear and other essentials, thereby guaranteeing resources to the poorest in the district. Committees of this kind devoted to the reorganisation of production were a common feature of Republican Spain, and was linked in particular to the influence of the anarchist trade union CNT (Guillamón 2011) (Figure 4). 
Each family in the community was assigned a quantity of supplies based on the number of children, sharing equally with class or ideological distinction. The initial aim was to create a physical space for storing goods, some of them obtained by forcible seizure from the wealthier, although they were initially given financial compensation. The early period of La Cooperativa was well received and popular amongst the majority of the population. However, as the war progressed the militia began to demand more supplies for troops at the fronts, and the committee took on a war economy with significantly fewer resources, and began to requisition goods from even the poorest social groups. Combined with the end of financial compensation this saw the popularity of La Cooperativa decline sharply.

\section{Stage 2: October 1937 to November 1938}

The second period of the war era in Santo Adriano is remembered as a time of violence and repression. In the immediate aftermath of the fall of the Republican northern fronts in the last days of October 1937 the Nationalist army arrived in the area. In the municipal capital, Villanueva, the 'conquest' of the Republican zone was marked with gestures of celebration by the troops. These included the 'artilleros' who arrived in mid-November of 1937 and specifically the 'Batería-37' which located its command centre in the nearby village of Proaza, and which was placed in overall control of Santo Adriano. In the neighbouring villages such as Villanueva, a more informal base of authority was established, usually in the homes of families related to the new regime. These houses functioned as the visible presence of the new regime and its power structures, and were where interrogations took place, contact with the network of local collaborators was maintained, and where the public humiliations of women related to prominent Republicans and militiamen took place.

This is a stage characterized by the omnipresence of the army and its violence. The repression began with the arrest of the local committee organizers and the persecution of militiamen who had taken refuge close to their villages and families. The Nationalist troops exploited the pre-existing tensions within the community: for example, the claims made by those who had been affected by requisitions were not addressed by the army: instead they treated the requisitions as an ordinary criminal act bearing individual responsibility, rather than as a result of the war, which would have placed them within public liability. This was used both to justify the political persecution of those who carried out the requisitions and to avoid paying any financial compensation. The Nationalist army also continued the requisitions, while still blaming the Republicans for the situation.

All of the interviewees from Villanueva recalled an event during this period: the capture and murder of a young militiaman named Julio (nicknamed 'de la Teyera' in the neighbourhood of the village where he lived) in April 1938. After his arrest 
he was brutally beaten and paraded through the village, with the clear intention of intimidating the population. After this particular "Via Crucis" (one interviewee compared the victim with the figure of Christ, with his long beard and his bloody face) he was summarily executed without trial in the nearby village of Proaza. He had not committed a violent crime and the general perception of the population at the time was that it was an injustice, but one to which no one could react without fear of reprisals.

During this period the persecution of the families of militiamen, especially women, was particularly notable. Usually the wives or sisters of fugitive militiamen were pressured to betray their locations, and were subjected to different kinds of humiliations. In interviews it was also explained how the daughters of the socialists who had acted as coordinators of the committee were forced to clean the homes of families who were collaborating with the new power. While it is known that rapes of Republican women occurred during this period they are difficult to record, because the majority of interviewees felt an understandable reluctance to provide information. Only one woman interviewed in the village of Castañéu described gang-rapes committed by a group of Nationalist soldiers. Of the three known victims one young woman subsequently committed suicide. This type of victim is often forgotten when counting the costs of conflicts, and rape during or as a weapon of war was recorded in other parts of Spain during the Civil War (Preston 2006; Rittner and Roth 2012).

\section{Stage 3: November 1938 to June 1940}

During this final period the regular army occupiers were gradually replaced by other forces such as the Guardia Civil, a militarised police force. Despite the overall decline in violence several Republican militia forces remained in operation in the area, albeit in very small numbers. The last death in action of one of these militiamen occurred in June 1940, marking the end of paramilitary violence in the Santo Adriano area, although militia groups remained active in Asturias more generally until 1952.

In terms of casualties, the first stage of the conflict saw at least two militiamen from Santo Adriano killed on the Oviedo front, but no political persecution in the area during this period. However, during the second and third periods under Nationalist control of the area three people died in prison, seven were executed and one more died on the battle front, bringing the total casualties recorded from the interviews alone to thirteen. As such this information is incomplete, but gives a good general indication of the varying degrees of violence in the community during the different periods. To the population of Santo Adriano the worst violence occurred not during the 'war' years but in the repression afterwards, including rapes and extra-judicial killings. 


\section{Archaeology of the conflict: the caves occupied by militiamen between 1937 and 1940}

Since the start of the twenty-first century the archaeological study of the Spanish Civil War has emerged as a sub-discipline of Spanish archaeology in its own right. Initially focused on the exhumation and identification of the victims of fascist massacres buried in mass graves it has grown to incorporate battlefield archaeology; aviation archaeology; the archaeology of concentration camps; bunkers; and air raid shelters (e.g. Ferrándiz 2013; González-Ruibal 2008, 2012). Elsewhere in the world the archaeology of twentieth century conflict has drawn extensively on documentary sources and oral histories alongside the archaeological record, and this is certainly true in Spain where many of the excavated mass graves were first identified through eyewitness or perpetrator testimony. There are relatively few archaeological studies of Civil War sites in Asturias: these include a study of trench systems from the siege of Oviedo (Fanjul Peraza et al. 2014); a study of bullets found in this excavation (Díaz Herrero, Feito Álvarez and Fanjul Peraza 2014); and studies of fortified sites from the same siege (Álvarez Martínez and Requejo Pagés 2008; Álvarez Martínez et al. 2009).

The limestone mountains of Santo Adriano contain numerous caves of various sizes, some of them easily accessible and others less so: some of the latter served as refuges or operating bases for militiamen during and after the war. Following the collapse of the Republican front many militiamen were unable to return to their homes in areas then under Nationalist control, with many who tried to return facing reprisals including imprisonment or summary execution. Other caves were occupied at later dates as operating bases or general refuges. An overview of research on Spanish Civil War caves in another area of Asturias was presented at a recent conference (see Bondura, Pita and Fanjul Peraza 2015).

Three caves containing traces of occupation by militiamen were discovered in Santo Adriano during general surveys of the area focusing primarily on Palaeolithic rock carvings: two of the three were identified with caves mentioned in the oral histories collected earlier. The three caves, described in more detail below, were studied through site visits and the graffiti and rock carvings dating from the Civil War period were recorded (Figure 5).

\section{Cave 1}

The traditional name of the cave is 'Cueva de los Fugaos' (cave of the refugees), in reference to the presence of the militiamen. It is located on the south face of the Sierra de los Collaos mountain with the entrance located ten metres up a vertical limestone wall, making access to the cave difficult and improving its defensive 
position. The cave has a flat floor making it relatively easy for occupants: from the entrance it is possible to observe a number of different roads and traditional paths between the villages. Around the cave are the remains of trenches dug to protect the entrance, and inside the team discovered the remains of cans and household goods as well as fragments of newspapers. This cave is where 'Modesto', the last of the militiamen of Santo Adriano committed suicide in June 1940. One interviewee recalled how the inaccessible cave was used by the militiamen:

Por aquél espeñadeiru arriba a la cueva, ellos tenían una escalera de palos de avellano...que plegaba y tirabanla desde arriba...una vez todos adentro, pues tiraban por ella p'arriba, plegabanla.

In the cliff there was a cave, and they had a ladder made of sticks of hazel which could be folded and lifted up from above. Once all were inside the cave, they would pull up the ladder.

Inside the cave itself, another interviewee stated that:

Había somieres, y allí había unas calamilleras...tenían como una corripina y allí era la cocina. Había libros, ferramientas, hachos.

There were mattresses, and there was a chain to hang pots on. They had as small enclosed space and there was a kitchen. There were books, tools, axes.

\section{Cave 2}

We do not know the traditional name of this cave located in the south face of the Sierra de los Collaos. It is very small and the entrance is difficult to locate. From the small entrance it is possible to gain access to a secondary tunnel that connects with a small open area (about two meters long and one meters wide) with a flat floor. This space was adapted by the militiaman to create an adequate space to live and sleep. The remains of hearths can still be seen in the cave, and from the entrance the main road of the Trubia Valley is visible, as well as other traditional paths and roads. At the entrance of the cave there is an inscription on the wall (Figure 6), which reads

\section{La República \\ La libertad \\ La cultura \\ La enseñanza}

[The Republic

Freedom 
Culture

Education]

\section{Cave 3}

El Veiru cave is on the north side of the Sierra de los Collaos. Its entrance is very narrow and difficult to locate, although not too far from an old parish road that passes through the village of Castañéu. The cave is narrow (no more than a meter and a half wide) and about fifteen metres long. It is extremely damp, making it unpleasant for long-term habitation, but its value lay in its strategic position with a good view of the main road that connected Castañéu with the Trubia Valley, as well as its invisibility as the entrance is hidden behind vegetation. One interviewee recalled:

En una cueva que hay en Valle del Covón...encima, entras así por un sitiu así redondu que casi nun lu ves... encima del furacu que entra pa la cueva... pasadon así por riba, vi yo al mi perro mirar así p'allí...Cuando yo llegué allí había 11 hombres mirando pa la Cuesta'l Saltu. Al volver ya no estaban allí, ya se metieran pa'l furacu...Por la Peña Sabadía hubo muchos fugaos.

In a cave in the Valle del Covón ... from above, you can enter through a small hollow. I saw my dog looking at the spot. When I got there there were 11 men looking for la Cuesta'l Salto. When I returned they were no longer there, and they had gone into the cave ... In the Peña Sabadia there were many refugees.

Various graffiti were recorded in this cave. The first depicts the flag of the Spanish Section of the International Communist Party, showing the militia group's political affiliation (Figure 7). The interviews revealed that the Communists were only a small group in Villanueva. The individuals who established the Cooperative were socialists linked with the UGT trade union and the Spanish Socialist Party the PSOE. However the popularity and membership of the Communist Party grew amongst troops on the battle fronts, with membership rising from a pre-war 80,000 to more than 300,000 by October 1937 (Hernández 2010, 356).

The second carving consists of the initials of the militiamen resident in the cave, and information about the dates of entry and departure from the cave:

Entra 10/21/1937 (Arrived 21/10/1937)

Sale (Departed) (Figure 8) 
On 23 October 1937 the militiamen received orders from the commanders of the Popular Front to leave the line in the Puerto Ventana (the last Republican front in the area), and they fled in all directions. Based on the dates in the cave the militia fugitives in El Veiru probably came from other fronts that would have been demobilized earlier. As the departure date is not specified it is possible that it was gradual.

From the interviews we know that the militia fugitives in El Veiru were successfully reintegrated into their communities without suffering violent or legal repercussions, probably during the amnesties of 1938 which were granted by the new State in cases where there had been no violent crime. Although they were many cases in which the amnesties were not respected, this does not appear to have been the case here. This 'happy ending' led to the appearance of a popular folk song in the community at the time, recounting anecdotes of this militia group. The song was recorded through two different interviews in the nearby villages of Castañéu and Perlavia. The different versions of the song showed a high degree of similarity. The melody was also recorded in one of the interviews.

\section{Discussion: Preserving and Presenting the Heritage of the Militia Caves}

The exhumation of mass graves has done much to break the national 'Pact of Silence' around the events of the Civil War period in Spain (Ferrándiz 2013). On a local level the process is more complicated: in some cases, fragments of material and intangible heritage were quietly preserved; in others there remains an individual and collective reluctance to break the silence and confront difficult, painful and divisive narratives. In these contexts, the work of the La PonteEcomuseum in recording the oral histories and archaeological traces of conflict in the Santo Adriano district offer an example of how they can be preserved and promoted for current and future generations.

The Ecomuseum is committed to innovation in the dissemination of local history and archaeology, and to this end established a series of activities to share and preserve the data collected during the interviews and the surveys of the caves. In June 2013 they hosted a public event to present the initial findings of the oral historical and archaeological work. In April 2014 They held a conference on cultural heritage, including a special performance of the song of the Republican militia collected during the interviews (Figure 9). The interpretation of the music and lyrics was carried out by pupils from the Ecomuseum music school, led by Asturian musician Xuacu Amieva, best known for his participation in the awardwinning album Santiago with Irish folk group The Chieftains (Figure 10). The presentation served as a way to introduce the story of the song and its main characters. The music was used as a method by which to disseminate local history 
to different groups: music students, conference participants, and local people who may not be specialists or even interested in history.

Perhaps the most significant outcome of the research is that based on the Ecomuseum's archaeological and heritage management work the third cave site, El Veiru, has been added to the Asturian government's register of cultural heritage sites relating to the Spanish Civil War. This provides the site with legal protection as well as recognition of its heritage value on a regional level.

Future plans for the Civil War heritage of the district are grounded in an appreciation of the Ecomuseum's role as creators and curators of memory narratives. These plans include:

- Continuing oral history research as salvage work: the Civil War is at the very edge of living memory in the area as well as nationally and internationally, a crucial period for collecting the last remaining traces.

- Developing a distinctively local history of the Civil War, drawing on the oral histories as well as existing documentary histories and recent and ongoing archaeological research.

- Forging stronger links between the material traces of conflict in the area and the intangible heritage of folklore and memory.

- Developing Civil War heritage trails of these sites in the villages of Villanueva and Castañéu, based on guides and information panels: the Ecomuseum currently runs tours and trails on a variety of themes including Palaeolithic archaeology, medieval history and architecture, and the local iron mining industry.

While the caves themselves are inaccessible to visitors (this was, of course, why they were used in the first place) there are a number of sites in the district that can be visited and interpreted as Civil War heritage. These include military remains such as bunkers, the sites of buildings burned by militia forces, the buildings used by La Cooperativa as storage and distribution sites, and sites of imprisonment, public humiliation and execution. By building Civil War heritage activities and resources into its existing programme of diverse archaeological and historical tours the Ecomuseum hopes to begin to legitimise and normalise the discourses around the conflict in the local community, and to promote a local heritage narrative alongside and, where necessary, in opposition to national narratives.

This paper aimed to examine the distinctive contribution of La Ponte-Ecomuseum to the management of Spanish Civil War heritage in the Santo Adriano district of Asturias. Drawing on an established framework for examining the dynamics of conflict memory we raised a set of questions that can now be addressed concerning the role of the Ecomuseum in the creation and promotion of heritage 
narratives around the Civil War in Santo Adriano. In the first instance, the oral history project and archaeological survey work outlined in the body of the paper demonstrate the Ecomuseum's commitment to crafting narratives of memory and heritage that directly challenge the enduring silence around the Civil War period in much of contemporary Spanish culture and society. A notable example of this is the recording of accounts of rape by Nationalist soldiers in the district, which had hitherto remained unmentioned due in part to shame and silence within families as well as communities. Having worked to generate these memory narratives the Ecomuseum has worked to actively promote them in a number of different arenas. This includes lobbying for the inclusion of the cave sites in official heritage listings and an active programme of community education, with a series of future plans for further development outlined above. The aims and achievements described are distinctly local, with the Ecomuseum taking on the role of community heritage stakeholder; nonetheless they fit clearly within the framework of memory dynamics outlined by Ashplant, Dawson and Roper and developed within an archaeological framework by Moshenska. The diversity of this work and the clear focus on preserving and communicating tangible and intangible heritage of the Spanish Civil War offers a valuable case study in the role of grassroots heritage organisations in dealing with difficult pasts within local communities.

\section{Acknowledgements}

To the elderly people of Santo Adriano who maintain our memory, to the TERA archaeology company that collaborated in the archaeological fieldwork, and to the students and professor of the ecomuseum traditional music school for playing the song.

\section{References}

Alonso González, P., and J. Fernández Fernández. 2013. "Rural Development and Heritage Commons Management in Asturias (Spain): The Ecomuseum of Santo Adriano." Journal of Settlements and Spatial Planning 2: 245-253.

Alpert, M. 1994. A New International History of the Spanish Civil War. Basingstoke: Macmillan.

Álvarez Martínez, V., and O. Requejo Pagés. 2008. “El Nido de Ametralladoras de Fitoria (Oviedo, Asturias). Excavación Arqueológica en una Fortificación de la Guerra Civil Española." Complutum 19 (2): 89-101.

Álvarez Martínez, V., O. Requejo Pagés and N. Alonso Rodríguez. 2008. "La Arqueología de la Guerra Civil en Asturias: Estado de la Cuestión y una Propuesta 
de Actuación: el Complejo Fortificado de Las Matas (Oviedo)". Erada: Revista d'Historia Contemporánea d'Asturies 2: 79-115.

Ashplant, T.G., G. Dawson and M. Roper. 2000. “The Politics of War Memory and Commemoration: Contexts, Structures and Dynamics." In The Politics of War Memory and Commemoration, edited by T.G. Ashplant, G. Dawson and M. Roper, 385. London: Routledge.

Atalay, S. 2012. Community-Based Archaeology: Research With, By, and For Indigenous and Local Communities. Berkeley, CA: University of California Press.

Atalay, S., L.R. Clauss, R.H. McGuire and J.R. Welch, eds. 2014. Transforming Archaeology: Activist Practices and Prospects. Walnut Creek, CA: Left Coast Press.

Ayán Vila, X.M. 2014. "El Patrimonio de los Vencidos: Arqueología en Comunidades Subalternas." Tejuelo 19: 109-142.

Beevor, A. 2006. The Battle for Spain: The Spanish Civil War 1936-1939. London: Weidenfeld \& Nicolson.

Bondura, V., V.T. Pita and A. Fanjul Peraza. 2015. "Resistance, Refuge, and Retaliation: The Use of Caves During the Spanish Civil War in Asturias." Paper Presented at the 80 ${ }^{\text {th }}$ Annual Meeting of the Society for American Archaeology, San Francisco, California.

Díaz Herrero, M., F. Feito Álvarez and A. Fanjul Peraza. 2014. "Munición Extranjera en la Batalla de Oviedo 1936/37. Estudio Material de las Excavaciones Arqueológicas en el Pico Paisano". Trébole: Boletín Cultural de Asturias en América 3: $16-20$

Fanjul Peraza, A., R. Duarte, F. Feito Álvarez and C. Bracero. 2014. "The Forgotten Battle. Archaeology of the Spanish Civil War in the Trenches of Oviedo's Siege". Trébole: Boletín Cultural de Asturias en América 3: 21-33.

Fernández Fernández, J., P. Alonso González and O. Navajas Corral. 2015. "La Ponte-Ecomuséu: una Herramienta de Desarrollo Rural Basada en la Socialización del Patrimonio Cultural." La Descommunal 1 (2): 117-130.

Ferrándiz, F. 2013. Exhuming the Defeated: Civil War Mass Graves in 21st-century Spain. American Ethnologist 40 (1): 38-54.

González-Ruibal, A. 2012 "From the Battlefield to the Labor Camp: Archaeology of Civil War and Dictatorship in Spain.” Antiquity 86: 456-473. 
González-Ruibal, A. 2008. "Arqueología de la Guerra Civil española." Complutum 19 (2): 11-20.

González-Ruibal, A. 2007. "Making Things Public: Archaeologies of the Spanish Civil War." Public Archaeology 6 (4): 203-226

Guillamón, A. 2011. Los Comités de Defensa de la CNT en Barcelona (1933-1938). De los Cuadros de Defensa a los Comités Revolucionarios de Barriada, las Patrullas de Control y las Milicias Populares. Barcelona: Aldarull Edicions.

Hernández Sánchez, F. 2010. El PCE en la Guerra Civil (Doctoral Thesis). Facultad de Geografía e Historia: UNED

Kimeev, V.M. 2008. "Ecomuseums in Siberia as Centers for Ethnic and Cultural Heritage Preservation in the Natural Environment." Archaeology, Ethnology and Anthropology of Eurasia 35 (3), 119-128.

Moshenska, G. 2010. "Working with Memory in the Archaeology of Modern Conflict." Cambridge Archaeological Journal 20(1): 33-48.

Moshenska, G. and S. Dhanjal. 2012. "Introduction: Thinking About, Talking About, and Doing Community Archaeology." In Community Archaeology: Themes, Methods and Practices, edited by G. Moshenska and S. Dhanjal, 1-5. Oxford: Oxbow.

Moyer, T.S. 2007. "Learning Through Visitors: Exhibits as a Tool for Encouraging Civic Engagement Through Archaeology." In Archaeology as a Tool of Civic Engagement, edited by B.J. Little and P.A. Shackel, 263-77. London: Altamira.

Preston, P. 2006. The Spanish Civil War: Reaction, Revolution and Revenge. London: Harper Perennial.

Renshaw, L. 2011. Exhuming Loss: Memory, Materiality and Mass Graves of the Spanish Civil War. Walnut Creek, CA: Left Coast Press.

Rittner, C. and J.K. Roth. 2012. "Introduction: One of Many." In Rape: Weapon of War and Genocide, edited by C. Rittner and J.K. Roth. St Paul, MN: Paragon House.

\section{Figure captions}

Figure 1. Recording an oral history interview 
Figure 2. Site recording in Cueva'l Veiru

Figure 3. Location of the study area

Figure 4. Document issued by the Committee of Supplies of Santo Adriano in August 1936, noting the transfer of a weapon from a neighbor to defend the Committee. The document's signatory Jose Martinez Martinez was the mayor during the revolutionary period. He was executed on 8 May 1938 at 28 years old, and lies buried in the common grave in the cemetery of Oviedo. He was never accused of any violent crime, a fact verified in the interviews.

Figure 5. Archaeological sites cited in the text. 1. Cueva de los Fugaos. 2. Cueva con graffiti. 3. Cueva'l Veiru. Adapted from Mapa Topográfico Nacional de España (IGN) 1:25000 Hoja 52-2

Figure 6. Graffiti with text highlighted.

Figure 7. Graffiti in Cueva'l Veiru; the flag of the Spanish Communist Party.

Figure 8. Graffiti in Cueva'l Veiru; the initials of militiamen and date of entry and exit.

Figure 9. Melody of the Militia Song recovered during interviews. Translation of the lyrics: 'We were nine months, saved in the Veiru Cave, the first one was Luciano, the second was Oliverio, the third one was Avelino, and in the garret el Fardelu.'

Figure 10. The Asturian musician, Xuacu Amieva (second on the right) playing the 'militia song' with pupils of the ecomuseum music school. 